\title{
ODGOJ ZA VREDNOTE U ŠKOLI
}

\author{
Tanja Maltar Okun \\ Osnovna škola Sveti Petar Orehovec, Orehovec, Republika Hrvatska
}

\begin{abstract}
Sažetak
Mladi su u današnje doba materijalizma slabo upoznati s moralnim kategorijama i etičkim vrijednostima pa bi, po svemu sudeći, odgojnu krizu u kojoj se upravo nalazimo uvelike smanjilo promicanje vrijednosti (vrednota) kod mlađih generacija, napose u odgojno-obrazovnim ustanovama. U članku se raspravlja o samom pojmu vrijednosti te klasifikaciji spomenutog pojma, o mladima danas te značajnoj ulozi učitelja i škole u promicanju vrijednosti. Spomenuta je zadaća škole, a posebice učitelja, zauzimanje vodećih uloga u promicanju općeljudskih vrijednosti koje on ostvaruje posebno planiranim programima i aktivnostima, primjerima koje bira, a ponajviše svojim ponašanjem. Dobar odgojitelj treba djelovati na racionalnu, emocionalnu i voljnu sferu svakog odgajanika kako bi on usvojio navike moralnog ponašanja i djelovanja. Svjesni smo da bez vrijednosno usmjerenih mladih generacija ne možemo očekivati zdravo, savjesno i moralno društvo pa time ni napredak za našu zemlju.
\end{abstract}

Ključne riječi: mladi, moralnost, odgoj i obrazovanje, škola, vrijednosti (vrednote)

\section{UvoD}

Živimo u razdoblju znanstveno-tehničke revolucije, u društvu u kojem je zavladala posvemašnja erozija i kriza moralnih i etičkih vrijednosti koju, svjedoci smo, slijedi i odgojna kriza. Danas, više nego ikad, ljudska je zajednica zaokupljena pitanjem na koji način najbolje odgajati djecu te koje bi vrijednosti ona procesima učenja i odgoja trebala „prigrliti“. Osim što spomenuta vrijednost ili vrednota predstavlja sve „ono što je cilj čovjekova djelovanja; ono čemu se teži; ono do čega je ljudima stalo; ono što važi kao dobro, lijepo, sveto“ (Polić, 2001, str. 60), vrijednosti imaju i veliku usmjeravajuću funkciju u pogledu ponašanja jer, uz to što utječu na zauzimanje stavova spram relevantnih društvenih problema, djeluju i na svakodnevicu pojedinca, odnosno potiču ga u njegovim odlukama i sudovima, pomažu mu u nastojanju da racionalizira i oblikuje stavove i mnijenja, olakšavaju mu komunikaciju s drugima te predstavljaju važna uporišta u njegovu shvaćanju društvene okoline (Radin, 2001, str. 87). Možemo uvidjeti da su vrijednosti takve potrebe, stavovi i interesi koji su osobno i društveno poželjni, ali nikako ne i nametnuti (Ajduković, 1989).

Zadatak je svake zemlje voditi brigu o tome da njezine škole njeguju vrijednosti i norme koje su u temelju društvenog života (Marinović Bobinac, 2001). Stoga i u Hrvatskoj godinama unazad Ministarstvo znanosti i obrazovanja predlaže da školstvo Republike Hrvatske bude vrijednosno usmjereno ${ }^{1}$ s vrijednosno usmjerenim odgojem. Stoga su vrednote danas napose aktualne u odgojno-obrazovnim ustanovama gdje predstavljaju uporišnu točku odgojnog djelovanja (Hoblaj i Črpić, 2000, str. 360). Time škola uz obitelj postaje jedan od najznačajnijih prenositelja vrijednosti jer temeljem zakona ima pravo i dužnost da u suvremenom građan-

1 Ministarstvo znanosti i obrazovanja Republike Hrvatske, https://mzo.hr/hr/rubrike/udruge (4. 1. 2018). 
skom društvu kompetentno posreduje bitne vrednote ${ }^{2}$ kao što su iskrenost, ljubav, poštenje, dobrobit, tolerancija, sloboda, pravda, mir i druge.

Budući da su učenici u Hrvatskoj slabo upoznati s moralnim kategorijama i etičkim vrijednostima te nemaju izgrađen onakav individualni sustav vrijednosti kojim bi doprinijeli sveukupnoj kvaliteti društva u kojem živimo, potrebna nam je „stalna, stvarna i trajna revolucija i evolucija u prevrednovanju, obnavljanju i uvijek ponovnoj izgradnji svih temeljnih ljudskih vrednota" (Brnčić, 2009, str. 307).

\section{Određenje pojma vrijednosti}

Premda postoji više određenja pojma vrijednosti, u literaturi se uočavaju neka njihova zajednička obilježja, a prema kojima se može ustvrditi da su vrijednosti ili vrednote vjerovanja o poželjnim ciljevima ili ponašanjima koja nadilaze specifične situacije, usmjeravaju odabir i procjenu ponašanja te su hijerarhijski organizirane u sustave vrijednosti s obzirom na njihovu relativnu važnost za pojedinca (Schwartz i Bilsky, 1990). Iz toga proizlazi da su vrijednosti dispozicije usmjerene na ostvarivanje ciljeva koji su poželjni i vrijedni za čovjeka, a koje ga snažno i trajno pokreću na određene aktivnosti (Rot, 1978). Drugim riječima, vrijednosti su temeljna, relativno stabilna vjerovanja, nastala kao rezultat socijalizacije, pod utjecajem individualnog iskustva te društvenih i kulturnih čimbenika, i koja, na individualnoj razini, bitno utječu na stavove i ponašanja (Schwartz, 1996). Može se uočiti kako vrijednosti objedinjuju sve ono što unaprjeđuje ljudski život bez povrede drugih ljudi i društva kao cjeline (Zecha, 2007).

Pojedini autori ističu trajnost i stabilnost vrijednosti nakon formiranja vrijednosnog sustava, što ukazuje na to da jednom formiran, vrijednosni sustav ostaje tijekom života nepromijenjen (Feather, 1986; Franc, Sučić i Šakić, 2009), dok drugi autori smatraju kako se vrijednosni prioriteti pod utjecajem različitih čimbenika tijekom života ipak mijenjanju (Hoblaj, 2007; Visković, 2013). Pritom je važno uočiti kako se vrijednosti najčešće tumače kao relativan pojam, specifičan za svaku osobu, dok su vrijednosne orijentacije opće i trajne, jer općenito određuju djelovanje i ponašanje pojedinca (Havelka, 1975). Suprotno navedenome, neki autori vrijednosne orijentacije smatraju podložnima promjenama koje ovise o stupnju sazrijevanja pojedinca, kontekstu ili društvenoj situaciji u kojoj se on nalazi, vlastitim ciljevima i razmišljanjima o svijetu i sebi (Seligman i Katz, 1996).

Promišljajući o vrednotama, očigledan je njihov značaj za naš život ponajprije iz razloga što nam služe kao standardi na osnovu kojih procjenjujemo socijalne situacije i sebe. Nadalje, one predstavljaju izraz naših potreba i u funkciji su zadovoljenja tih potreba i, što je najvažnije, one su te koje nadahnjuju i motiviraju naš cjelokupni život.

\section{Klasifikacija vrijednosti}

S obzirom da se radi o bogatstvu značenja pojma vrijednosti, postoje brojne podjele $\mathrm{i}$ klasifikacije vrednota, a mogu se promatrati u četiri različite dimenzije. Najprije vrednota u sebi ili za sebe (ljubav, ljepota, prijateljstvo, istina, pravda), zatim vrednota kao zbilja koja vrijedi (umjetničko djelo, djelo pravde, istinita tvrdnja), nadalje vrednota kao subjektivna prednost (aspiracije, želje za nečim dobrim, istinitim, lijepim) i vrednota promatrana s povijesno-kulturnog stajališta (vrijednosni sustavi ili predodžbe koje pripadaju nekoj skupini, narodu ili povijesnoj epohi) (Hoblaj i Črpić, 2000, str. 362). Vrednota i u odgojno-obrazovnom području ima više dimenzija te se između subjekta (učenika) i objektivnog reda (sadržaja, ideala) uspostavlja određena polarizacija između pojedinca i skupine, osoba i stvari, pojedinca i ambijenta, prošlosti,

2 REPUBLIKA HRVATSKA / MINISTARSTVO PROSVJETE I ŠPORTA PROSVJETNO VIJEĆE: „Osnova za ustroj školstva Republike Hrvatske“ (Prijedlog za javnu raspravu). U: Školske novine, 51 (2000), 24-25 /Prilog/ str. 18. 
sadašnjosti i budućnosti, subjektivnog i objektivnog svijeta, prirodnog i kulturnog reda, stvarnog i mogućeg.

Mogu se razlikovati terminalne vrednote $\mathrm{i}$ instrumentalne vrednote pri čemu se terminalne odnose na ciljeve ljudske egzistencije, a u njima uočavamo osobne vrednote (mudrost, unutarnji sklad ličnosti, samopoštovanje) i društvene vrednote (mir u svijetu, sigurnost naroda) (Rokeach, 1973). Instrumentalne, pak, vrednote predstavljaju način života odnosno oblike ponašanja koji su sredstvo za postizanje ciljeva, u kojima razlikujemo vrednote kompetencije i moralne vrednote.

Neki autori razlikuju vrijednosti kao bihevioralne ideale (prosuđivanja što je dobro, a što loše) i vrijednosti kao preference za iskustvo kojima je uloga voditi osobu prema situacijama u kojima ona može iskusiti uzbuđenje, relaksaciju, pripadanje i sigurnost (Wagner i Sanchez, 2002). Jedna funkcija vrijednosti predstavlja standarde koji rukovode našim ponašanjem, a druga motivacijska odnosi se na komponentu koja izražava naše stremljenje prema stjecanju vrijednosti (npr. težimo biti pošteni). Ipak, vrijednosti se najčešće mogu razlikovati prema tipu motivacijskog cilja kojemu su usmjerene kao što su: moć, postignuće, hedonizam, poticaj, nezavisnost, univerzalizam, dobrohotnost, tradicija, konformizam i sigurnost (Schwartz, 1996).

Unatoč brojnim mišljenjima i podjelama vrijednosti, danas se sve više govori o dimenziji vrednota u sebi ili za sebe koja objedinjuje općeljudske vrijednosti pod kojima se podrazumijeva ljubav, dobrobit, čovjekoljublje, sloboda, pravda, mir, sveopće razumijevanje, ljudska i vjerska tolerancija te jednak i sveobuhvatan odgoj za sve ljude, a tu se pridodaju još i uvažavanje istine, poštenja, iskrenosti, čestitosti, ljudskog dostojanstva i prijateljstva.

Za vrijednosti je znakovit sustav ili ljestvica vrijednosti, gdje su materijalne vrijednosti na dnu, a duhovne pri vrhu vrijednosne ljestvice pri čemu se izgrađuje etički sustav vrijednosti nalik na piramidu široke osnovice konkretnih dobara i visokog vrha koji krase spomenute vrijednosti istine, dobrote, ljubavi, pravde, ljepote, svetosti i druge (Vukasović, 2010). Na samom je vrhu najviša vrijednost, „opće dobro“ prema kojemu se ravnaju sve druge vrijednosti i ono nema definiciju jer je jednostavno i ne sastoji se od dijelova, ali se ogleda u svemu „što omogućuje i potpomaže razvitak ljudskih odlika" te služi čovjekovu oplemenjivanju i usavršavanju kao humanog, društvenog i napose moralnog ljudskog bića (Vukasović, 2010, str. 104).

\section{Vrijednosti i mladi danas}

Još od antike, Platon je u pravilu preuzeo Sokratov etički stav da je potrebno rano spoznati istinske vrijednosti kako bi ih se moglo uvažavati i poštivati te da njihovo spoznavanje bitno utječe na konstituiranje i usmjerenje našega života i na našu životnu praksu u cjelini (Platon, 2009). Dakle, već u prvim godinama života djeca „upijaju“ moralni osjećaj o tome što je dobro, a što loše unutar kulture u kojoj žive. Iz toga proizlazi da se vrijednosti postupno usvajaju još u djetinjstvu, ponajprije procesom socijalizacije, pri čemu najznačajniju ulogu u njihovu prijenosu ima obitelji, škola i vršnjaci, a važno je zamijetiti i utjecaj društveno-povijesnih okolnosti te (jedinstveno) životno iskustvo pojedinca (Pennington, 1997). Unatoč navedenome, neosporno je da one već u razdoblju adolescencije pokazuju hijerarhijsko obilježje i ostaju kao takve relativno stabilne i trajne tijekom cijelog života (Beech i Schoeppe, 1974; Brim, 1996).

Razvidno je da učenici tijekom svog razvoja neke vrednote biraju i integriraju u vrijednosni sustav, dok druge odbijaju, sve do spomenutog razdoblja adolescencije koje je ključno za njihovo strukturiranje u vrijednosni sustav pri čemu je tim važnije ponuditi im istinske vrednote koje će ih usmjeravati, a ne sputavati odnosno ograničavati u životu. No taj je zadatak posebno zahtjevan.

Jedan od razloga je taj što je moderni svijet u kojem djeca danas žive orijentiran pretežno prema materijalizmu, odnosno prema lagodnom životu, što je razlog njihovom sve većem zatvaranju sustavu vrijednosti odraslih pri čemu se u njima "rađa“ sve više nemorala, nepošti- 
vanja i nebrige za druge te sebičnosti (egoizma), indiferentnosti i pohlepe. Uza sve to, javlja se i duboka ravnodušnost i antisocijalno ponašanje mladih naraštaja prema tradicionalnim vrijednostima i ulogama odraslih, što bi se moglo tumačiti nedostatkom značenja koje te vrijednosti i uloge mogu imati za njih. Pri tome stvaraju vlastitu subkulturu („mladenačku kulturu“) koja ima utjecaj na dezintegraciju sustava vrijednosti (Tomić-Koludrović i Leburić, 2001), što je također pokazatelj zakazivanja važnih društvenih mehanizama i autoriteta od kojih se mora zahtijevati znatno veći angažman.

Dokaz krize odgoja i vrijednosti u kojoj se nalazimo zasigurno potvrđuje i istraživanje „Siromaštvo u Hrvatskoj" (Vlahović i Rimac, 2004, prema Miliša i Tolić, 2010, str. 139) gdje su vrijednosti samoobrazovanja, empatičnosti i altruizma na samom dnu ljestvice prihvaćanja. Svjedoci smo i sami kako u Hrvatskoj sve više dolazi do rastakanja tradicionalnih vrijednosti uz nametanje novih, često upitnih ili neprihvatljivih, pa Hoblaj (2007) upozorava na paradoks prema kojem bi upravo do sada najbogatija generacija mogla vrijednosno i duhovno osiromašiti ukoliko je ne pokušamo „izliječiti“. Sasvim je razumljivo da: „Gdje čovjek kao duhovno biće hoće budućnost, trajno mora da hoće vrijednu sadašnjost, stalno mora bdjeti nad tim da mu sadašnji čas ne izmakne neoplođen vrednotom, kako mu ne bi prošao, kao da nikad i nije bio; ne smije dopustiti, da mu nestane u bezdanu ništavila, nego mora htjeti da u nj unese u bilo kojem obliku i smislu nešto trajno i umjeti da mu poda zazbiljnost“" (Vuk-Pavlović, 1996, str. 46).

Ljudi kao razumska i moralna bića ne smiju dopustiti „da djeca lutaju bez moralnih orijentira i vrijednosnih svjetionika, da se opredjeljuju za stavove koji negiraju moralne ljudske stečevine, kulturne i etičke vrijednosti“ (Vukasović, 2010, str. 102). Na taj i slične probleme suvremenog društva ne smijemo se oglušiti, već valjano odgovoriti kvalitetnim odgojem i obrazovanjem mladih naraštaja za vrijednosti.

\section{Škola za vrijednosti}

Odgoj i obrazovanje za vrijednosti jedno je od područja u kojem vladaju mnoga neslaganja, posebice oko pitanja koja se odnose na pristupe i metode podučavanja uz vrijednosti koje bi se trebale podučavati te uloge učitelja i škole. Tako da ideje o tome na koji način škola treba utjecati na razvoj vrijednosnog sustava učenika obuhvaćaju gotovo sve stupnjeve kontinuuma: od stavova prema kojima škola treba biti vrijednosno što je više moguće neutralna, do ideja prema kojima su učitelji svojevrsni propovjednici vladajućih vrijednosti u društvu, vrijednosti kojima trebaju učiti mlade generacije (Ledić, 1999). Mnogi autori naglašavaju kako je bespredmetno raspravljati o odgovornosti škole u promicanju vrijednosti jer je ona neupitna, s obzirom da djeca većinu djetinjstva provode u školi gdje se obrazovanje u cjelini temelji na vrijednostima. Kako se škola nalazi u javnom prostoru društva, neosporno je da je najprikladnija institucija modernoga doba koja proširuje oblike očekivana ponašanja pa je iz tog razloga nužno da bude vrijednosno usmjerena s vrijednosno usmjerenim odgojem (Hoblaj, 2007). „Odgoj se zbiva tamo i tada gdje se zbiva drugi i drukčiji čovjek kojem je drugi i drukčiji čovjek najveća potreba, te sam biva čovjekom pomažući drugome da to bude." (Polić, 2006, str. 84). Ulogu u provedbi odgoja za vrijednosti preuzima škola i planirani odgojno-obrazovni programi, no važno je primijetiti kako odgovornost roditelja za formiranje vrijednosnog sustava djeteta zapravo ne prestaje.

Nameće se pitanje koje su to vrijednosti koje škola „prenosi i odabire“ za odgoj svoje djece te kako se postavlja prema njima. Jedan od načina na koji se to najbolje vidi je u izboru znanja koja se prenose u školi, u pripremi škole za budućnost i samostalnost učenika, u odnosu škole prema problemima okoliša, kakvoj vrsti kvalitete škola teži, kako integrira učenike koji odudaraju od prosjeka, kako se nosi s pitanjima glede socijalne pravde, međusobnih odnosa, zdravlja i kvalitete života (Aspin, 1999). Uočavamo, dakle, kako učenici o vrijednostima uče tijekom cijelog boravka u školskoj sredini jer su one prisutne u svakom dijelu škole pa s tim u vezi Ryan (1993, str. 18) napominje kako se učenike najlakše uči poštenju ako, primjerice, duh poštenja „prožima svaki kutak škole.“ 
Kada govorimo o procesu odgajanja u školi, važno je uočiti dvije sastavnice - obrazovnu na spoznajnom (svijest) i odgojno-formirajuću na vrijednosno-moralnom području (savjest) kod koje se odgojni učinci očituju u poštenju i čestitosti, humanošću protkanim ljudskim uvjerenjima i stavovima, kulturnom odnosu prema ljudima i ljudskim vrednotama, u poštenim, pravednim i plemenitim postupcima. „Stoga je potrebna ravnoteža između ljudske svijesti i savjesti, njihovo suglasje i usklađeno očitovanje u ljudskim činima i svekolikom djelovanju“ (Vukasović, 2010, str. 98).

Upravo iz tog razloga treba imati na umu da se jednostrano intelektualističkim, didaktičko-materijalističkim i scijentističkim svođenjem zahtjevnog procesa odgajanja ne zapostavlja etičko-vrijednosna sastavnica života i izgrađivanje ljudskih odlika jer upravo uz njih pojedinac postaje uljuđenim ljudskim bićem.

\section{Moralna uloga učitelja}

Pri spomenu vrijednosti i morala prije svega se trebamo osvrnuti na učitelja kao ključnog čimbenika škole. On je taj koji mora zauzimati središnju ulogu, odnosno biti središnja ličnost u moralnoj socijalizaciji djece te,temeljem osnovne vrijednosne usmjerenosti unutar ostvarivanja nastavnog plana i programa, aktualizirati odgoj za vrijednosti. Pri tome je važno naglasiti kako je odnos vrijednosti i moralnosti blisko povezan te ih je gotovo nemoguće odvojiti pa se još od Aristotela sve vrijednosti smatraju podvrstama moralnosti (kao temeljne vrijednosti). Moralnost je intrinzična vrijednost i mora proizići iz ispravnoga djelovanja, a ne iz želje da se bude sretan ili da se ostvari kakva druga korist (Žitinski, 2008), a preduvjet za razvijanje moralnih vrijednosti je sloboda. S obzirom da odlike moralne osobe moraju biti razvijane intencionalnim odgojnim aktivnostima, zadatak učitelja i škole u moralnom odgoju djeteta treba biti od najveće važnosti (Ledić, 1999).

„Svako odgajanje, svaki se odgojni akt odigrava u neminovnom prepletu triju faktora: odgajanik - odgajatelj - vrijednost (kulturno dobro, ideal) pri čemu odgajatelj igra vidnu ulogu posrednika, katalizatora izbijajući iz kulturnog dobra sve imanentne odgojne sile, odgojne skokove, koji unapređuju, dižu i organiziraju odgajanikov psihizam i njegove duhovne mogućnosti.“ (Matičević, 1991, str. 196).

$\mathrm{Na}$ taj način izravnim pristupom odgojitelj ponajprije podučava temeljne ljudske vrijednosti (što zovemo „odgoj karaktera“) i posebno planiranim programima potiče u učenicima moralno mišljenje, promišljeno donošenja odluka i moralnih spoznaja (Fyffe, Hay i Palmer, 2004), dok neizravnim pristupom ističe samostalnost učenika u razlučivanju te kritičko mišljenje i rješavanje problema čime učenicima omogućuje da sami uvide što je moralno i ispravno (Hooper, Zbar, Brown i Bereznicki, 2003). „U odgojnom procesu pristupa još odgajatelj kao prevažan faktor sa svojom namjerom i planom, to će reći sa cijelom svojom psihičnošću, svojom psihičnom strukturom, koja sama pretstavlja zamršeni preplet prirodnih svojstava, iskustava, vrednosnih pogleda i ideala odgojnoga subjekta." (Matičević, 1991, str. 196).

Pri tome se najveći značaj učitelja u promicanju vrijednosti ogleda u pomaganju učenicima da usvoje moralne pojmove, stavove, norme, kategorije, pravila, načela, da shvate moralno-etičke vrednote, da ovladavaju sustavom vrijednosti kao i kriterijima pomoću kojih mogu ocijeniti jesu li određeni postupci u skladu s moralnim zahtjevima (Vukasović, 1991). Ponekad pri tome koristi metodu uvjeravanja pri čemu određenu moralnu pojavu tako jasno objasni i pokazuje njezinu moralnu opravdanost i etičku ljepotu da ona budi ugodne osjećaje kao i osjećaje dužnosti i odgovornosti, pa „unutarnjom motivacijom potiče na moralno djelovanje“ (Vukasović, 1991, str. 56). Kod takve metode učitelj se služi živim riječima, izražajnim čitanjem umjetničkih tekstova, dramatizacijom, glazbom, interpretacijom slika, vrednovanjem i zauzimanjem stava o svemu što se ima etički vrednovati kako bi se odgoj za vrednote ostvario aktivnostima i programima koji su učenicima dovoljno pristupačni i zanimljivi. Dakle, vrijednosti koje 
učitelj smatra važnima izražava učenicima sadržajem koji podučava, načinima podučavanja, primjerima koje bira te odnosom prema učeniku.

Također, promišljajući svoju ulogu u podučavanju vrijednosti, učiteljima trebaju biti jasne njihove vlastite vrijednosti i sklonosti te nikako ne mogu biti neutralni u pogledu vrijednosti, jer je njihovo stimuliranje i „osobina njihove profesije“ (Veugelers, 2000, str. 44). Isto tako loša je i indoktrinacija gdje moralnost određuju sudbina, hir ili vanjske sile (umjesto razuma i društva), a jednako je štetan i propust u ponudi vrednota jer se i na taj način mladi ostavljaju na milost i nemilost predrasuda ili zabluda okoline (Hoblaj i Črpić, 2000) što nikako nije cilj odgojitelja. Dakle, dok filozof razmišlja o problemima moralnosti i odgoja, zadatak je učitelja potražiti priču i dosjetiti se primjera kojim će poželjnu vrijednost približiti učeniku ili sam može učeniku bitimoralni primjer (Ledić, 1999) jer poželjno je da ponašanje učitelja bude u skladu s vrijednostima o kojima govori. „Zato nije najvažnije ono što odgojitelj može reći o vrijednostima; najvažnije je svjedočanstvo o vrijednosti što ga u stvarnom postojanju daje odgojitelj i cjelokupna sredina sa visokom vrijednosnom sviješću." (Hoblaj, 2007, str. 320).

Uočavamo da učitelj mora biti živi uzor istinskih vrijednosti gdje mu se pridaje duhovna uloga oblikovanja naravi i društvenog bića djeteta, a taj je zadatak specifično zahtjevan za svakog odgojitelja jer se vrijednosti ne mogu samo nametnuti kao ustaljene norme, navike strukture društvene sredine. Stoga je iznimno važno da se u školi ostvaruju sve etape odgojnog procesa kako bi se postigao sklad misli (ratio), riječi (oratio) i djela (operatio) (Greengrass, Leslie i Raylor, 1994, str. 164). Tako da će iskusni i dobri odgojitelji u moralnom odgoju istodobno djelovati na racionalnu, emocionalnu i voljnu sferu odgajanika učeći ga što je dobro i moralno, a što zlo i nemoralno. Dakle, cilj je odgojitelja da njegove riječi, a još više njegova djela, dopru do srca učenika te pobude njegove emocije, raspoloženja i potaknu ga na djelovanje. Kao rezultat takvog odgoja i obrazovanja za vrijednosti ističu se navike moralnog ponašanja $i$ djelovanja što je, pak, usko povezano s formiranjem pozitivnih osobina volje i karaktera koji su i krajnji cilj cjelokupnog procesa.

Ponekad učeniku (odgajaniku) nije dovoljno da zna što je istinito (dobro), nego treba htjeti djelovati u skladu s istinom (dobrom) da bi djelovanje bilo moralno ispravno. Dakle, „težište moralne odluke i djelovanja premješta se iz razuma u volju, $\mathrm{tj}$. od onoga što se zna na ono što se hoće (od znanja na 'vrijednosti')“ (Kujundžić, 1991, str. 65). Prema tome, on ne može djelovati u skladu s istinom ukoliko istinu ne zna te će moći djelovati tek onda i onoliko kada i koliko mu istina bude znana, a steći (spoznati) može je obrazovanjem („moralno neutralno“), no isto tako, nažalost, može i ostati pasivan unatoč poznavanju istine ili je zlorabiti pa učiniti suprotno jer moralna spoznaja nije jamstvo za ispravno moralno djelovanje (Kujundžić, 1991). Upravo iz tog razloga važno je učenike moralno odgojiti odnosno ispuniti ih vrijednim ciljevima.

Nažalost, danas se u školama sve više zapostavlja odgojna sastavnica jer je briga za ispunjavanjem obrazovnih zadataka potisnula odgajanje, vrednote i duhovnost, a znamo kako je obrazovanje koje je lišeno odgajanja zapravo štetno. Upravo je zadatak pedagogijske aksiologije u vrijednosnom utemeljenju odgojnog ideala te u vrijednosnom obogaćivanju spomenutog odgojnog procesa koji se tek smatra završenim usvajanjem određenih sustava društvenih vrijednosti kod pojedinca.

\section{Škola za budućnost}

Budućnost edukacije sve se više ogleda u njezinoj vodećoj ulozi u „ideološkoj i moralnoj sferi“. Danas se u školama promiču vrijednosti koje čine temelj aktivnog i odgovornog građanstva, a u posljednje se vrijeme od škole posebice traži da preuzme zadatak uvođenja u nove vrednote kao što su ekologija, ljudska prava, međunarodnost, suradnja, mir, solidarnost, zdravlje i druge. 
Kako je za održivi razvoj nužna edukacija usmjerena na jačanje vrijednosti, to će svakako podrazumijevati kritičnost kao i odupiranje ideologizaciji i indoktrinaciji (Babić, Irović i Sentjabov, 2008).

Brze i značajne promjene, uvjetovale su i razne promjene klasičnog poimanja uloge učitelja pa on više nije samo pružatelj informacija, već postaje predstavnik društva, izvor znanja, pomagač u učenju, uzor, vođa grupe, zamjenski roditelj, prijatelj, osoba od povjerenja i slično (Armstrong, 2006; Ilić, Ištvanić, Letica, Sirovatka i Vican, 2012). Uočavamo kako svekoliki razvoj obvezuje učitelja da na nov način počne misliti o školi (Hentig, 1997), a sve to pretpostavlja i traži učitelja (i učenika) kao sudionika i čimbenika tih promjena, ali i kao korektora mogućih deformacija koje će te promjene izazvati (Pivac, 2009). No, upravo zahvaljujući odgoju i obrazovanju za vrijednosti mladi naraštaji kreiraju nove poželjne vrijednosti osposobljavajući se da u odrasloj dobi kompetentno izgrađuju društvo budućnosti.

\section{ZAKUUČAK}

Ne postoji jedinstven pristup odgoju i obrazovanju za vrijednosti, ali s obzirom da su one socijalno utemeljene, škola preuzima zadatak širiti temeljne ljudske vrijednosti odgojem i obrazovanjem. Pri tome odgoj ne smije biti vrijednosno neutralan, već duboko vrijednosno angažiran gdje se njegov smisao izražava ne u ljudskom informiranju već formiranju (u skladu s istinskim ljudskim svrhama). Isto tako, samoostvarenja u odgoju neće biti bez osjećaja odgovornosti, samopožrtvovnosti, dužnosti, strpljenja i privrženosti, a podučiti svakog pojedinca da odgovorno upravlja sobom kao i vlastitim životom zadatak je dostojan svake pomoći. Kako se mladi danas povlače u svijet individualnosti i pokazuju sve manje morala i ljudskosti, neophodno jeusavršavati njihov smisao za vrijednosti i obogaćivati ih novim vrednotama u čemu se ogleda najvažnija uloga škole, a posebice odgojitelja (učitelja) u njoj. Današnja odgojna kriza „žeđa“ za obnovom duhovnosti i oživljavanjem moralnih i odgojnih vrijednosti što zahtijeva znatno veći angažman i vrijednostima bogato pedagoško usavršavanje i samih odgojitelja o temeljnim etičkim, duhovnim, kulturnim i odgojnim vrijednostima.

Važno je naglasiti da učenike moralno odgajamo ukoliko uz učenje moralnog ponašanja i moralnog djelovanja potičemo u njima još i moralne navike, a ponekad još i voljnu snagu i karakterne odlike kao što su upornost, odlučnost i dosljednost kako bi naposljetku s ljubavlju „prigrlili“ i živjeli moralne vrijednosti. Krajnja svrha odgoja treba biti potpun čovjek, ličnost razvijene i svijesti i savjesti pri čemu su bitne unutarnje promjene, očovječenje, razvijanje smisla za vrijednosti, njegovanje plemenitih osjećaja, snaženje volje i oblikovanje karaktera.

Stoga Vukasović (2010, str. 99) s pravom primjećuje da su nam kao kruh potrebni „zdravi, sposobni i čestiti ljudi, ljudi čista uma, spretnih ruku, snažne volje i čiste savjesti koji mogu i žele biti nositelji svekolikog gospodarskog, društvenog, kulturnog, demografskog i moralnog napretka“. Imajmo na umu kako bez moralne preobrazbe nema ni odgojne, bez odgojne nema čestitih osobnosti, ljudi ni naroda, a naposljetku bez njih nema i ne može biti napretka ni bolje budućnosti.

\section{LITERATURA}

Ajduković, M. (1989). Vrijednosne orijentacije i očekivanja maloljetnih delikvenata: uzrok i posljedice delikvencije? Zagreb: Narodne novine, Pravni fakultet.

Armstrong, T. (2006). Višestruke inteligencije u razredu. Zagreb: Educa.

Aspin, D. D. (1999). The Nature of Values and Their Place and Promotion in Schemes of Values Education. Educational Philosophy and Theory, 31(2), 123-143. 
Babić, N., Irović, S. i Sentjabov A. (2008). Edukacija, vrijednost i održivi razvoj. U: V. Uzelac i L. Vujičić (ur.), Cjeloživotno učenje za održivi razvoj, sv. 1. (str. 119-124). Rijeka: Učiteljski fakultet u Rijeci.

Beech, R. P. i Schoeppe, A. (1974). Development of value system in adolescents. Developmental Psychology, 10(5), 644-656.

Brim, O. G. (1996). Socijalization through the life-cycle. U: O. G. Brim i S. Wheeler (ur.), Socialization after childhood (str. 1-49). New York: Wiley.

Brnčić, J. (2009). Afirmacija istinskih vrednota i rehabilitacija ljudske osobe danas. Konkretne zadaće. Nova prisutnost, 7(2), 307-309.

Feather, N. T. (1986). Cross-cultural studies with the Rokeach Value Survey: the Flinders program of research on values. Australian Journal of Psychology, 38(3), 269-283.

Franc, R., Sučić, I. i Šakić, V. (2009). Vrijednosti kao rizični i zaštitni čimbenici socijalizacije mladih. Diaconvensia: teološki prilozi, 16(1-2), 135-146.

Fyffe, L., Hay, I. i Palmer, G. (2004). Issues and Concerns in Children's Value Education. Educating: Weaving Research into Practice, 2. Griffith University: School of Cognition, Language and Special Education, 104-111.

Greengrass, M., Leslie, M. i Raylor, T. (1994). Samuel Hartlib and Universal Reformation: Studies in Intellectual Communication. Cambridge:Cambridge University Press.

Havelka, N. (1975). Istraživanje vrijednosti kod nas. Psihologija, 8(3-4), 139-150.

Hentig, von H. (1997). Humana škola. Zagreb: Educa.

Hoblaj, A. (2007). Odgoj i obrazovanje za vrijednosti u kontekstu vrijednosno usmjerenoga društva. Dijete idruštvo, 9(2), 311-332.

Hoblaj, A. i Črpić, G. (2000). Bitne vrednote u odgoju mladih naraštaja s posebnim osvrtom na školski vjeronauk. Bogoslovska smotra, 70(2), 359-393.

Hooper, C., Zbar, V., Brown, D. i Bereznicki, B. (ur.) (2003). Values education study: Literature review. U: Values education study - Final report (str. 168-212). Melbourne: Curriculum Corporation. Preuzeto s http://www.curriculum.edu.au/verve/_resources/VES_Final_Report14Nov.pdf, 17.2.2018.

Ilić, I., Ištvanić, I., Letica, J., Sirovatka, G. i Vican, D. (2012). Upravljanje razredom. Zagreb: Agencija za strukovno obrazovanje i obrazovanje odraslih u suradnji s British Councilom.

Kujundžić, N. (1991). Aristotel - odgoj između teorije i prakse. U: N. Kujundžić i I. Marjanović, Personalistička pedagogija Stjepana Matičevića (str. 53-66). Zagreb: Katehetski salezijanski centar.

Ledić, J. (1999). Škola i vrijednosti. Rijeka: Filozofski fakultet u Rijeci.

Marinović Bobinac, A. (2001). Obitelj i škola. U: V. Ilišin (ur.), Djeca i mediji (41-78). Zagreb: Državni zavod za zaštitu obitelji, materinstva i mladeži i IDIZ.

Matičević, S. (1991). K problematici funkcije odgajanja i jedne nauke o njoj. U: N. Kujundžić i I. Marjanović (ur.), Personalistička pedagogija Stjepana Matičevića (163-199). Zagreb: Katehetski selezijanski centar.

Miliša, Z. i Tolić, M. (2010). Kriza odgoja i ekspanzija suvremenih ovisnosti. Medianali, 4(8), 135-164.

Ministarstvo znanosti i obrazovanja Republike Hrvatske. Preuzeto s https://mzo.hr/hr/rubrike/ udruge, 4.1.2018.

Pennington, C. D. (1997). Osnove socijalne psihologije. Jastrebarsko: Naklada Slap.

Pivac, J. (2009). Izazovi školi. Zagreb: Školska knjiga.

Platon (2009). Država. Zagreb: Naklada Jurčić.

Polić, M. (2001). Čovjek, odgoj, svijet: mala filozofijskoodgojna razložba. Zagreb: Radionica Polić.

Polić, M. (2006). Vrijednosno i spoznajno u suvremenom odgoju. U: M. Polić (ur.), Činjenice $i$ vrijednosti (str. 65-85). Zagreb: HFD.

Radin, F. (2001). Vrijednosti i neprihvatljiva ponašanja. U: V. Ilišin (ur.). Djeca i mediji (86-99). Zagreb: Državni zavod za zaštitu obitelji, materinstva i mladeži i IDIZ.

Republika Hrvatska/Ministarstvo prosvjete i športa Prosvjetno vijeće (2000), Osnova za ustroj školstva Republike Hrvatske, (Prijedlog za javnu raspravu). U: Školske novine, 51(24-25) /Prilog/ str. 18. 
Rokeach, M. (1973). The nature of human values. London: University Press. Preuzeto s https:// archive.org/details/natureofhumanval00roke, 5.2.2018.

Rot, N. (1978). Osnovi socijalne psihologije. Beograd: Zavod za udžbenike i nastavna sredstva.

Ryan, K. (1993). Mining the Values in the Curriculum. Educational Leadership, 51(3), 16-18.

Schwartz, S. H. (1996). Value priorities and behavior: Applying a theory of integrated value systems. U: C. Seligman, M. J. Olson i P. M. Zanna (ur.), The Psychology of Values: The Ontario Symposium, 8, (str. 1-24). Preuzeto s https://books.google.hr/books?hl=hr\&lr=\&id=DACsdMk7qqoC\&oi=fnd \&pg=PA1\&dq=Shalom+H.+SCHWARTZ,+(1996).+Value+priorities+and+behavior:\&ots=u3oHzoly $\mathrm{v5} \&$ sig=oEkMBKaDDmCMLkyXNdFiN_Qu4ZM\&redir_esc=y\#v=onepage\& $q \& f=f a l s e ~ 30.1 .2018$.

Schwartz, S. H. i Bilsky, W. (1990). Toward a theory of the universal content and structure of values: Extensions and cross-cultural replications. Journal of Personality and Social Psychology, 58(5), 878-891.

Seligman, C. i Katz, A. N. (1996). The dynamics of value system. U: C. Seligman, J. M. Olson i M. P. Zanna (ur.), The Psychology of Values:The Ontario Symposium, Vol. 8, (str. 53-75) . Preuzeto s https://books.google.hr/books?hl=hr\&lr=\&id=DACsdMk7qqoC\&oi=fnd\&pg=PA53\&dq=The+dyn amics+of+value+systems\&ots=u3oHzoGxtb\&sig=oomuE41E3bEwGJxU69vownk7MvE\&redir_es $c=y \# v=$ onepage \&q=The\%20dynamics\%20of\%20value\%20systems\&f=false, 21.1.2018.

Tomić-Koludrović, I. i Leburić, A. (2001). Skeptična generacija: životni stilovi mladih u Hrvatskoj. Zagreb: AGM.

Veugelers, W. (2000). Different Ways of Teaching Values. Educational Review, 52(1), 37-46.

Visković, I. (2013). Međugeneracijski prijenos vrijednosti s roditelja na djecu adolescente u općini Tučepi. Školski vjesnik, 62(2-3), 253-268.

Vukasović, A. (1991). Odgoj za etičke vrijednosti u obitelji i školi. Obnovljeni život: Časopis za filozofiju i religijske znanosti, 46(1), 49-58.

Vukasović, A. (2010). Odgojna preobrazba u teleologijskom i aksiologijskom ozračju. Odgojne znanosti, 12(1), 97-117.

Vuk-Pavlović, P. (1996). Filozofija odgoja. Zagreb: Hrvatska sveučilišna naklada.

Wagner, C. C. i Sanchez, F. P. (2002). The role of values in motivational interviewing. U: W. R. Miller i S. Rollnick (ur.), Motivational Interviewing: Preparing People for Change (284-298). New York: The Guilford Press.

Zecha, G. (2007). Opening the Road to Values Education. U: N. D. Aspin i D. J. Chapman (ur.), Values Education and Lifelong Learning, Vol. 10, (str. 48-60).

Žitinski, M. (2008). Etičke implikacije psihodinamičkih teorija. Nova prisutnost, 6(3), 323-336.

\title{
Values Education in School
}

\begin{abstract}
Nowadays, in the age of materialism, young people are insufficiently acquainted with moral categories and ethical values. Therefore, the education crisis we have found ourselves in would be greatly reduced if values were better promoted in younger generations, mostly in educational institutions. The paper discusses the very concept of values and its classification, young people today, and the significance of the role the teachers and school have in promoting values. The task that schools have, and especially teachers, is to take the leading role in promoting universal human values (such as love, liberty, welfare, honesty, sincerity, peace, etc.) through specially designed curricula, activities and examples, but above all, by setting an example by their own behaviour. A good teacher should have impact on the rational and emotional dimension, and willingness of each student, so they could acquire the patterns of moral behaviour and actions. We are well aware that without value-oriented young generations we can neither expect healthy, conscientious and moral society, nor prosperity of our country.
\end{abstract}

Keywords: young people, morality, education, school, values 


\section{Bildung für Werte in der Schule}

Zusammenfassung: Junge Menschen sind im heutigen Zeitalter des Materialismus nur unzureichend mit moralischen Kategorien und ethischen Werten vertraut. Aller Wahrscheinlichkeit nach würde die Erziehungskrise, die wir derzeit erleben, durch die Förderung der Werten in jüngeren Generationen, insbesondere in Bildungseinrichtungen, stark gemindert werden. Der Artikel befasst sich mit der Definition und Klassifizierung des Begriffs Werte, mit den jungen Menschen von heute und einer bedeutenden Rolle von Lehrern und Schulen bei der Förderung von Werten. Diese Aufgabe der Schule, insbesondere der Lehrer, besteht darin, die allgemeinen Werte, die er mit speziell geplanten Programmen und Aktivitäten, den von ihm gewählten Entscheidungen und vor allem mit seinem Verhalten erreicht, zu fördern. Ein guter Pädagoge muss zur rationalen, emotionalen und willentlichen Ebene eines jeden Lernenden durchdringen, um ihm die Gewohnheiten moralischen Verhaltens und Handelns nahe zu bringen. Wir sind uns bewusst, dass es ohne eine werteorientierte junge Generation keine gesunde, gewissenhafte und moralische Gesellschaft geben kann und wir damit keinen Fortschritt für unser Land erwarten können.

Schlüsselwörter: Jugendliche, Moral, Erziehung und Bildung, Schule, Werte 